\title{
Awards Presented at the 46th Annual Meeting of the BEHAVIOR GENETICS ASSOCIATION
}

\author{
Thursday, June 23, Brisbane, Australia
}

The Association's annual awards were presented at the Banquet, held at Brisbane City Hall, Brisbane, Australia. President-Elect Hermine Maes served as the master of ceremonies.

The 39th Annual Thompson Award for the best oral presentation by an associate member was presented by Benjamin Neale to Robert Maier for the presentation entitled "Multivariate Genetic Risk Scores Increase Risk Prediction Accuracy for a Wide Range of Traits."

The 4th Annual Rowe Award for the best poster presentation by an associate member was presented by Eric Turkheimer to Milana Smolkina for the poster entitled "Cannabis and Depression: A Twin Model Approach to Co-morbidity."

The 13th Annual Fuller and Scott Award for outstanding early career contributions to the field was presented by Meike Bartels to Sara Hart.
The 16th Annual Fulker Award for the outstanding paper in Behavior Genetics during the past year was presented by Valerie Knopik on behalf of John Hewitt, Editor of Behavior Genetics, to Daniel Briley et al., "Nonparametric estimates of gene $\mathrm{x}$ environment interaction using local structural equation modeling."

Nicholas Martin presented the James Shields Award for excellence in twin research to John Hewitt.

Past-President Paul Lichtenstein presented the 39th annual Dobzhansky Award for outstanding lifetime contributions to the field of behavior genetics to Jaakko Kaprio.

Respectfully Submitted,

Valerie Knopik

Secretary, Behavior Genetics Association

Paul Lichtenstein

Past President, Chair of the BGA Awards Committee 